\title{
Evaluation of Five Probiotic Products for Label Claims by DNA Extraction and Polymerase Chain Reaction Analysis
}

\author{
JEANNE DRISKO, MD, CNS,* BETTE BISCHOFF, RD,* CHERYL GILES, MD,* MARTIN E. ADELSON, PhD, $\dagger$ \\ RAJA-VENKITESH S. RAO, PhD,$\dagger$ and RICHARD McCALLUM, MD*
}

\begin{abstract}
Label claims were evaluated for five probiotic products. Specific oligonucleotide primers were designed for 11 species from the Bifidobacterium, Lactobacillus, and Streptococcus genera. Polymerase chain reaction, gel electrophoresis, and amplicon excision with DNA sequencing were performed: Sequence analysis and DNA homology comparisons followed. Bifidobacterium bifidum was not detected in two of the five samples by PCR analysis. Also, Lactobacillus species were found in two of the five product samples for which the species was not listed as an ingredient. We conclude that (1) lack of B. bifidum in two probiotic products may be attributed to different preparation standards among probiotic manufacturers, and (2) indentification of additional Lactobacillus species may represent contamination of the samples due to manufacturers utilizing shared equipment to produce all probiotics.
\end{abstract}

KEY WORDS: DNA; PCR; probiotic; supplement label claims; Lactobacillus; Bifidobacterium species.

Given as replacement therapy in the form of nutritional supplements, probiotics, or symbiotic microflora have been shown to have significant benefits in the treatment of multiple gastrointestinal and extraintestinal disorders (1-4). It is predicted that probiotics will gain widespread use in the future. They are currently widely available to the consumer and regulated as nutritional supplements through the Dietary Supplement Health and Education Act.

The quality of probiotic products varies and depends on preparation standards, shipping conditions, storage environment, and consumer handling (5). Because probiotics are living bacteria cultures, quality and handling are important to ensure that appropriate and proper colonies are present and to prevent colony decay. Obviously, probiotics must be safe and tested for human use, and maintain

\footnotetext{
Manuscript received August 13, 2004; accepted November 2, 2004.

From the *University of Kansas Medical Center, Kansas City, Kansas, and $\dagger$ Medical Diagnostic Laboratories, Hamilton, New Jersey, USA.

Address for reprint requests: Jeanne A. Drisko, MD, CNS, University of Kansas Medical Center, Program in Integrative Medicine, 3901 Rainbow Boulevard, Kansas City, Kansas 66160, USA; jdrisko@kumc.edu.
}

viability and beneficial properties after processing, culture, and storage.

We report the evaluation of five commercially available probiotic products for label claims. Microflora species stated on the label to be present in the five products were evaluated by DNA extraction and polymerase chain reaction (PCR) analysis.

\section{METHODS}

Samples. Five probiotic products that are commonly available to consumers were selected. The five probiotic products were obtained at the point of purchase and immediately refrigerated or stored at room temperature depending on the label directions. Samples were transferred overnight to Medical Diagnostic Laboratories (MDL; Hamilton, New Jersey) in Styrofoam containers with cold packs.

DNA Extraction. DNA was extracted from the probiotic samples as follows: $1 \mathrm{~g}$ of probiotic sample was dissolved in $1 \mathrm{ml}$ of TE buffer (10 mM Tris- $\mathrm{HCl}$ [pH 8.0], $1 \mathrm{~m} M$ EDTA). Four hundred seventy microliters of each sample was treated with $25 \mu \mathrm{l}$ of $10 \%$ SDS and $10 \mu \mathrm{g} / \mu \mathrm{l}$ of proteinase $\mathrm{K}$ and incubated for $2 \mathrm{hr}$ at $55^{\circ} \mathrm{C}$. Samples were transferred to Eppendorf phase lock gel tubes, $500 \mu$ l of phenol:chloroform:isoamyl alcohol 
TABLE 1. PRIMERS USED FOR PCR

\begin{tabular}{|c|c|c|c|}
\hline Bacterial species & Primer & Orientation* & Primer sequence \\
\hline \multicolumn{4}{|l|}{ Lactobacillus delbrueckii } \\
\hline \multirow[t]{2}{*}{ subsp. bulgaricus } & Ldel-7 & $\mathrm{F}$ & $5^{\prime}$-ACA GAT GGA TGG AGA GCA GA-3' \\
\hline & Lac-2 & $\mathrm{R}$ & 5'-CCT CTT CGC TCG CCG CTA CT-3' \\
\hline \multirow[t]{2}{*}{ Lactobacillus salivarius } & Lsal-1 & $\mathrm{F}$ & $5^{\prime}$-AAT CGC TAA ACT CAT AAC CT- $3^{\prime}$ \\
\hline & Lsal-2 & $\mathrm{R}$ & 5'-CAC TCT CTT TGG CTA ATC TT-3' \\
\hline \multirow[t]{2}{*}{ Lactobacillus plantarum } & Lpla-3 & $\mathrm{F}$ & 5'-ATT CAT AGT CTA GTT GGA GGT-3' \\
\hline & Lpla-2 & $\mathrm{R}$ & 5'-CCT GAA CTG AGA GAA TTT GA-3' \\
\hline \multirow[t]{2}{*}{ Lactobacillus rhamnosus } & $\mathrm{Lu}-5$ & $\mathrm{~F}$ & 5'-CTA GCG GGT GCG ACT TTG TT-3' \\
\hline & Rha-II & $\mathrm{R}$ & 5'-GCG ATG CGA ATT TCT ATT ATT-3' \\
\hline \multirow[t]{2}{*}{ Lactobacillus acidophilus } & Laci-I & $\mathrm{F}$ & $5^{\prime}$-TGC AAA GTG GTA GCG TAA GC-3' \\
\hline & $23-10 \mathrm{C}$ & $\mathrm{R}$ & 5'-CCT TTC CCT CAC GGT ACT G-3' \\
\hline \multirow[t]{2}{*}{ Bifidobacterium infantis } & Bifinfant-F & $\mathrm{F}$ & $5^{\prime}$-TGT CTC CAT CGA AGT TGA TC-3' \\
\hline & Bifinfant-R & $\mathrm{R}$ & $5^{\prime}$-AAC TTC TTC TCG AAG AGC TC-3' \\
\hline \multirow[t]{2}{*}{ Lactobacillus casei } & Lactcase-F & $\mathrm{F}$ & 5'-TGT CTC CAT CGA AGT TGA TC-3' \\
\hline & Lactcase-R & $\mathrm{R}$ & $5^{\prime}$-AAC TTC TTC TCG AAG AGC TC-3' \\
\hline \multirow[t]{2}{*}{ Lactobacillus brevis } & L.bre-F & $\mathrm{F}$ & $5^{\prime}$-ATG CAC AAA CGA CTG AGT CAT A-3' \\
\hline & L.bre-R & $\mathrm{R}$ & $5^{\prime}$-ACG CAT GTA GTC ATC CGT AAT A-3' \\
\hline \multirow[t]{2}{*}{ Bifidobacterium lactis } & Bifi.Lac-F & $\mathrm{F}$ & $5^{\prime}$-ATG CAC AAA CGA CTG AGT CAT A-3' \\
\hline & Bifi.Lac-R & $\mathrm{R}$ & $5^{\prime}$-ACG CAT GTA GTC ATC CGT AAT A-3' \\
\hline \multirow{2}{*}{ Streptococcus thermophilus } & Stp Th-F & $\mathrm{F}$ & $5^{\prime}$-CAC TAT GCT CAG AAT ACA-3' \\
\hline & Stp Th-R & $\mathrm{R}$ & 5'-CGA ACA GCA TTG ATG TTA-3' \\
\hline \multirow[t]{4}{*}{ Bifidobacterium bifidum } & Bifbif-F & $\mathrm{F}$ & 5'-TAC GAG ATT TGA GCC ACT GT-3' \\
\hline & Bifbif-R & $\mathrm{R}$ & $5^{\prime}$-CGC TGG CAA CAC AAA TCA TC-3' \\
\hline & BIFI-GAL-F & $\mathrm{F}$ & $5^{\prime}$-TGT CAT GTA CTT CTT CCG CGA C-3' \\
\hline & BIFI-GAL-R & $\mathrm{R}$ & $5^{\prime}$-AGG TTG ATG GTG AAG GTC TTG C-3' \\
\hline
\end{tabular}

*F, Forward primer; R, reverse primer.

(25:24:1) was added and mixed well, and the mixture was centrifuged for $15 \mathrm{~min}$ at $12,000 \mathrm{rpm}$. The supernatant was transferred to fresh $1.5-\mathrm{ml}$ microcentrifuge tubes and DNA precipitation was performed by adding $40 \mu \mathrm{l}$ of $3 \mathrm{M}$ sodium acetate and $800 \mu 1$ of $100 \%$ ethyl alcohol in each tube and kept overnight at $-20^{\circ} \mathrm{C}$. Tubes were centrifuged for $15 \mathrm{~min}$ at $14,000 \mathrm{rpm}$, and the DNA pellet was washed with $70 \%$ alcohol, and dried in Centrivap concentrator (Labconco). DNA was dissolved in $20 \mu \mathrm{l}$ of nuclease-free water and quantified with an Eppendorf biophotometer. For PCR reactions, DNA was diluted to a final DNA concentration of $0.2 \mu \mathrm{g} / \mu 1$.

PCR Analysis. MDL designed specific oligonucleotive primers for 11 species from the Bifidobacterium, Lactobacillus, and Streptococcus genera reported by label claims to be in all or some of the five products.

Unless otherwise noted, PCR conditions for each bacterial species were $0.2 \mu \mathrm{g} / \mu 1 \mathrm{DNA}, 10 \mathrm{~m} M$ Tris- $\mathrm{HCl}$ (pH 8.3), $50 \mathrm{~m} M$ $\mathrm{KCl}, 1.5 \mathrm{mM} \mathrm{MgCl}$, a $200 \mu M$ concentration of each dATP, dCTP, dGTP, and dTTP, a $1 \mu M$ concentration of the respective forward and reverse primers presented in Table 1, and 2.5 units of Applied Biosystems AmpliTaq DNA polymerase.

Each PCR product was amplified according to the following conditions: $95^{\circ} \mathrm{C}$ for $3 \mathrm{~min}$, followed by PCR cycles of denaturation at $94^{\circ} \mathrm{C}$ for $30 \mathrm{sec}$, annealing at temperatures specified in Table 2 for $60 \mathrm{sec}$, and extension at $72^{\circ} \mathrm{C}$ for $1 \mathrm{~min}$. Each reaction concluded with a 10 -min final extension at $72^{\circ} \mathrm{C}$. The number of amplification cycles, the expected amplified product size, and the literature reference for each PCR are presented in Table 2.

PCRs, gel electrophoresis, and amplicon excision with purification and concentration determination were performed. Direct sequencing of PCR products was performed utilizing the forward reaction primer. Sequence analysis and DNA homology comparisons followed.
Additional PCR experimentation was performed to assay for the presence of Bifidobacterium bifidum in Products 1 and 3. Primers used were 5'-TGT CAT GTA CTT CTT CCG CGA C-3' (BIFI-GAL-F) and 5'-AGG TTG ATG GTG AAG

TABLE 2. PCR AMPLIFICATION CONDITIONS

\begin{tabular}{|c|c|c|c|c|}
\hline Species & $\begin{array}{l}\text { Annealing } \\
\text { temperature }\end{array}$ & $\begin{array}{l}\text { No. } \\
\text { cycles }\end{array}$ & $\begin{array}{l}\text { Product } \\
\text { size (bp) }\end{array}$ & Ref. No. \\
\hline $\begin{array}{l}\text { Lactobacillus delbrueckii } \\
\text { subsp. bulgaricus }\end{array}$ & $55^{\circ} \mathrm{C}$ & 35 & 450 & 6 \\
\hline Lactobacillus salivarius & $60^{\circ} \mathrm{C}$ & 35 & 411 & 6 \\
\hline Lactobacillus plantarum & $60^{\circ} \mathrm{C}$ & 35 & 248 & 6 \\
\hline Lactobacillus rhamnosus & $62^{\circ} \mathrm{C}$ & 35 & 113 & 6 \\
\hline Lactobacillus acidophilus & $68^{\circ} \mathrm{C}$ & 45 & 210 & 6 \\
\hline Bifidobacterium infantis & $62^{\circ} \mathrm{C}$ & 40 & 422 & This study \\
\hline Lactobacillus casei & $60^{\circ} \mathrm{C}$ & 40 & 420 & This study \\
\hline Lactobacillus brevis & $62^{\circ} \mathrm{C}$ & 35 & 514 & This study \\
\hline Bifidobacterium lactis & $62^{\circ} \mathrm{C}$ & 35 & 557 & This study \\
\hline Streptococcus thermophilus* & $58^{\circ} \mathrm{C}$ & 35 & 968 & 7 \\
\hline Bifidobacterium bifidum $\dagger$ & $\begin{array}{c}52,54, \\
56,60, \\
62,64^{\circ} \mathrm{C}\end{array}$ & $35-40$ & 422 & This study \\
\hline
\end{tabular}

*Reaction conditions for $S$. thermophilus PCR were $0.2 \mu \mathrm{g} / \mu 1$ DNA, $10 \mathrm{~m} M$ Tris- $\mathrm{HCl}$ (pH 8.3), $50 \mathrm{mM} \mathrm{KCl}, 1.5 \mathrm{mM} \mathrm{MgCl}$, a $200 \mu M$ concentration of each dATP, dCTP, dGTP, and dTTP, $1 \mu M$ Stp Th-F, $1 \mu M$ Stp Th-R, 0.75 unit Invitrogen High Fidelity DNA polymerase. Amplification conditions were $95^{\circ} \mathrm{C}$ for $3 \mathrm{~min} ; 35$ cycles (denaturation at $94^{\circ} \mathrm{C}$ for $20 \mathrm{sec}$, annealing at $58^{\circ} \mathrm{C}$ for $30 \mathrm{sec}$, extension at $68^{\circ} \mathrm{C}$ for $30 \mathrm{sec} ; 68^{\circ} \mathrm{C}$ for $5 \mathrm{~min}$ of final extension. Reaction conditions varied regarding $\mathrm{MgCl}_{2}$ concentration $(1.5,2$, or $2.5 \mathrm{mM}$ ) as well as Taq polymerase (2.5 units Applied Biosystems Ampli Taq DNA polymerase or 1 unit Invitrogen Platinum Taq High Fidelity DNA polymerase. 
GTC TTG C-3' (BIFI-GAL-R). Reaction conditions were as follows.

- For Taq DNA polymerase (USB): $5 \mu 1$ conc. DNA, $10 \mathrm{~m} M$ Tris- $\mathrm{HCl}$ (pH 8.6), $50 \mathrm{mM} \mathrm{KCl}, 1.5 \mathrm{mM} \mathrm{MgCl} 2$, a $200 \mu M$ concentration of each dATP, dCTP, dGTP, and dTTP, a $1 \mu M$ concentration of BIFI-GAL-F, $1 \mu M$ BIFI-GAL-R, 2.5 units Taq DNA polymerase

- For Platinum Taq High Fidelity (Invitrogen): $5 \mu \mathrm{l}$ conc. DNA, $20 \mathrm{~m} M$ Tris- $\mathrm{HCl}$ (pH 8.3), $40 \mathrm{mM} \mathrm{NaCl,} 2 \mathrm{mM}$ sodium phosphate, $0.1 \mathrm{~m} M$ EDTA, $1 \mathrm{~m} M$ DTT, $50 \%(\mathrm{v} / \mathrm{v})$ glycerol, $2 \mathrm{mM} \mathrm{MgSO}$; a $200 \mu M$ concentration of each dATP, dCTP, dGTP, and dTTP, $1 \mu \mathrm{M}$ BIFI-GAL-F, $1 \mu \mathrm{M}$ BIFI-GAL-R, 1 unit Platinum Taq DNA Polymerase High Fidelity

The positive control included was Bifidobacterium bifidum purchased from the American Type Cultures Collection (ATCC; Type Strain 29521). Amplification conditions were as follows.

- For Taq DNA polymerase (USB): $94^{\circ} \mathrm{C}$ for $3 \mathrm{~min}$; 40 cycles (denaturation at $94^{\circ} \mathrm{C}$ for $1 \mathrm{~min}$, annealing at $62^{\circ} \mathrm{C}$ for $1 \mathrm{~min}$, extension at $72^{\circ} \mathrm{C}$ for $1 \mathrm{~min} ; 72^{\circ} \mathrm{C}$ for $10 \mathrm{~min}$ of final extension

- For Platinum Taq High Fidelity (Invitrogen): $94^{\circ} \mathrm{C}$ for $3 \mathrm{~min} ; 35$ cycles (denaturation at $94^{\circ} \mathrm{C}$ for $15 \mathrm{sec}$, anneal- ing at $62^{\circ} \mathrm{C}$ for $25 \mathrm{sec}$, extension at $72^{\circ} \mathrm{C}$ for $\left.20 \mathrm{sec}\right) ; 72^{\circ} \mathrm{C}$ for $5 \mathrm{~min}$ of final extension

The product size was 513 base paris.

Additionally, Lactobacillus delbrueckii subsp. bulgaricus was assayed for in all five probiotic samples. Two products had an additional strain identified that was not listed on the label. Detection of Lactobacillus delbrueckii subsp. bulgaricus PCR products in unreported probiotic samples was as follows.

- Sample: $5 \mu \mathrm{l}, 2 \mu \mathrm{l}, 5 \mu \mathrm{l}$ (1:10 dil.), $5 \mu \mathrm{l}$ (1:100 dil.)

- Positive control: $5 \mu 1$

- Negative control: $5 \mu 1 \mathrm{H}_{2} \mathrm{O}$; negative on a separate gel

\section{RESULTS}

A systemic molecular approach using the polymerase chain reaction (PCR), followed by DNA sequence analysis of the PCR products, was undertaken to gather direct evidence for the presence of bacteria stated to be present in the probiotic products.

A summary of the bacterial species that were amplifiable by PCR with species identity confirmed by DNA sequencing is presented in Table 3 . Three representative

TABle 3. Summary of BACterial SPeCIES Amplifiable By PCR

\begin{tabular}{|c|c|c|c|}
\hline & Species & PCR-positive & Sequence confirmation* \\
\hline \multicolumn{4}{|c|}{ Product 1} \\
\hline 1 & Lactobacillus acidophilus & $\mathrm{X}$ & $\mathrm{X}$ \\
\hline 2 & Lactobacillus brevis & $\mathrm{X}$ & $\mathrm{X}$ \\
\hline 3 & Lactobacillus delbrueckii subsp. bulgaricus & $\mathrm{X}$ & $\mathrm{X}$ \\
\hline 4 & Lactobacillus casei & $X$ & $X$ \\
\hline 5 & Lactobacillus plantarum & $\mathrm{X}$ & $\mathrm{X}$ \\
\hline 6 & Lactobacillus rhamnosus & $\mathrm{X}$ & $\mathrm{X}$ \\
\hline 7 & Lactobacillus salivarius & $\mathrm{X}$ & $\mathrm{X}$ \\
\hline 8 & Streptococcus thermophilus & $\mathrm{X}$ & $\mathrm{X}$ \\
\hline 9 & Bifidobacterium infantis & $\mathrm{X}$ & $\mathrm{X}$ \\
\hline 10 & Bifidobacterium bifidum & $\begin{array}{l}\text { PCR-negative } \\
\text { multiple bal }\end{array}$ & igure 1. \\
\hline \multicolumn{4}{|c|}{ Product 2} \\
\hline 1 & Bifidobacterium lactis & $X$ & $\mathrm{X}$ \\
\hline 2 & Lactobacillus acidophilus & $\mathrm{X}$ & $\mathrm{X}$ \\
\hline 3 & Lactobacillus delbruecki subsp. bulgaricus & $\mathrm{X}$ & $\mathrm{X}$ \\
\hline 4 & Lactobacillus rhamnosus & $\mathrm{X}$ & $\mathrm{X}$ \\
\hline 5 & Streptococcus thermophilus & $\mathrm{X}$ & $\mathrm{X}$ \\
\hline \multicolumn{4}{|c|}{ Product 3} \\
\hline 1 & Lactobacillus acidophilus & $\mathrm{X}$ & $\mathrm{X}$ \\
\hline 2 & Lactobacillus delbruecki subsp. bulgaricus & $\mathrm{X}$ & $\mathrm{X}$ \\
\hline 3 & Bifidobacterium bifidum & $\begin{array}{l}\text { PCR-negative } \\
\text { multiple bal }\end{array}$ & Igure 1. \\
\hline \multicolumn{4}{|c|}{ Product 4} \\
\hline 1 & Bifidobacterium infantis & $\mathrm{X}$ & $\mathrm{X}$ \\
\hline 2 & Lactobacillus acidophilus & $\mathrm{X}$ & $\mathrm{X}$ \\
\hline \multicolumn{4}{|c|}{ Product 5} \\
\hline 1 & Bifidobacterium breve & $\mathrm{X}$ & $\mathrm{X}$ \\
\hline 2 & Bifidobacterium longum & $\mathrm{X}$ & $\mathrm{X}$ \\
\hline 3 & Lactobacillus acidophilus & $\mathrm{X}$ & $\mathrm{X}$ \\
\hline 4 & Lactobacillus casei & $X$ & $X$ \\
\hline 5 & Lactobacillus plantarum & $X$ & $\mathrm{X}$ \\
\hline 6 & Lactobacillus rhamnosus & $\mathrm{X}$ & $\mathrm{X}$ \\
\hline
\end{tabular}

*Species identity confirmed by DNA sequencing. 
PCR gels encompassing detection of four distinct bacterial species are presented in Figure 1.

It was not possibly to amplify DNA specific for Bifidobacterium bifidum by PCR from two probiotic samples. To verify that the lack of amplification was not a result of the particular primer pair selected, we designed a new set of primers (BIFI-GAL-F and BIFI-GAL-R) and optimized profiles and concentrations of PCR reagents. These primers were designed to amplify a 513-bp fragment from the published $\beta$-galactosidase sequence for $B i$ fidobacterium bifidum (accession No. AJ224435). Initial parameter modifications amplified multiple PCR bands, supporting the results from our previous studies that Bifidobacterium bifidum is not detectable in either probiotic sample. However, substitution of the Platinum High Fidelity polymerase (Invitrogen) for Taq DNA polymerase (USB) did amplify a band that migrated to approximately $500 \mathrm{bp}$, which is close to the expected size of a Bifidobacterium bifidum specific amplification (513 bp).

The initial quantity of PCR product was insufficient for confirmatory DNA sequencing and GenBank database sequence homology comparisons. To increase the quantity and quality of the PCR product prior to submission for DNA sequencing, multiple PCR rections were performed and the PCR products were pooled, concentrated, and purified by agarose gel electrophoresis. The concentration of the resulting fragment was determined prior to submission for DNA sequencing.

The DNA sequencing and subsequent homology search utilizing a BLAST query of the NCBI GenBank database revealed that the PCR products were not Bifidobacterium bifidum. If the fragments were an actual amplification of the $\beta$-galactosidase gene of Bifidobacterium bifidum, close to $100 \%$ sequence identity with accession No. AJ 224435 would have been expected. Figures 2A and B reveal that the percentage identity between Bifidobacterium bifidum and the DNA sequence from the amplified product of Products 1 and 3 was 38.3 and $30.6 \%$, respectively. Although certainly not high enough to confirm a match, the highest homology match in the database was actually for Bifidobacterium longum (85\% for Product 1 and $81-86 \%$ for Product 3 ). We hypothesize that the amplified product was from Bifidobacterium infantis or another Bifidobacterium spp. for which the corresponding $\beta$-galactosidase sequence has not been deposited in the NCBI database.

With a single exception, all bacterial species tested for were detected in the probiotic samples by PCR analysis and confirmed by DNA sequencing. Another important finding was the detection of Lactobacillus species in two of the five product samples for which the species was not listed as an ingredient.

\section{Lactobacillus delbrueckii subsp. bulgaricus PCR}

(Products 1, 2, and 3)

Product size is approximately 450 base pairs.

Confirmed as positive by PCR and DNA Sequencing:

\begin{tabular}{|l|l|l|}
\hline Lane & Species & Probiotic samples \\
\hline 1 & - & Low DNA mass ladder \\
\hline 2 & Lactobacillus delbrueckii & Product 1 \\
\hline 3 & Lactobacillus delbrueckii & Product 2 \\
\hline 4 & Lactobacillus delbrueckii & Product 3 \\
\hline
\end{tabular}

Lactobacillus salivarius PCR

(Product 1, approximately 411 base pairs)

Lactobacillus plantarum PCR

(Products 1 and 5, approximately 248 bps)

Confirmed as positive by PCR and DNA Sequencing:

\begin{tabular}{|l|l|l|}
\hline Lane & Species & Probiotic samples \\
\hline 1 & - & Low DNA mass ladder \\
\hline
\end{tabular}

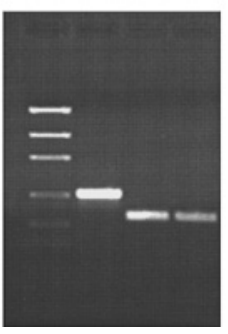

\begin{tabular}{|l|l|l|}
\hline 2 & Lactobacillus salivarius & Product 1 \\
\hline 3 & Lactobacillus plantarum & Product 1 \\
\hline 4 & Lactobacillus plantarum & Product 5 \\
\hline
\end{tabular}

\section{Lactobacillus acidophilus PCR}

(Products 1, 2, 3, 4, and 5; approximately 210 base pairs)

Confirmed as positive by PCR and DNA Sequencing:

\begin{tabular}{|l|l|l|}
\hline Lane & Species & Probiotic samples \\
\hline 1 & - & Low DNA mass ladder \\
\hline 2 & Lactobacillus acidophilus & Product 1 \\
\hline 3 & Lactobacillus acidophilus & Product 2 \\
\hline 4 & Lactobacillus acidophilus & Product 4 \\
\hline 5 & Lactobacillus acidophilus & Product 5 \\
\hline 6 & Lactobacillus acidophilus & Product 3 \\
\hline
\end{tabular}

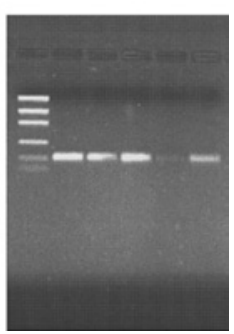

Bifidobacterium bifidum PCR Rxn 1: Bifbif-F/ Bifbif-R primers

(No clear band is present in products 1 or 3 . A very strongly positive $B$. bifidum control migrates to $600 \mathrm{bps}$, which is higher than the expected 422 bps provided by Genbank Accession \# U09831.1.

Bifidobacterium bifidum PCR RXn 2: BIFI-GAL-F / BIFI-GAL-R primers (Product 1, approximately 500 bps, closest homology to B. longum; positive control migrates higher at 512 bps)

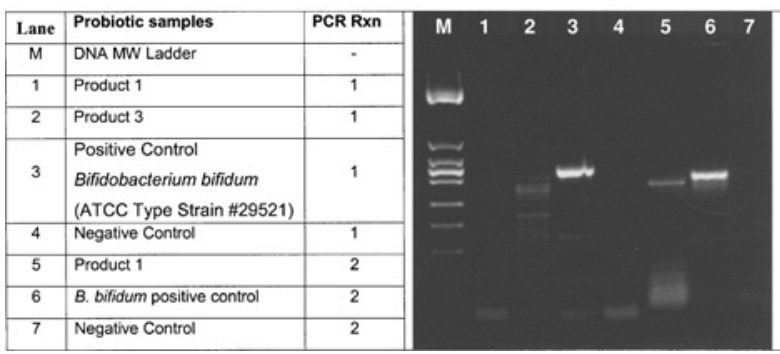

Fig 1. Representative PCR amplifications. 
A

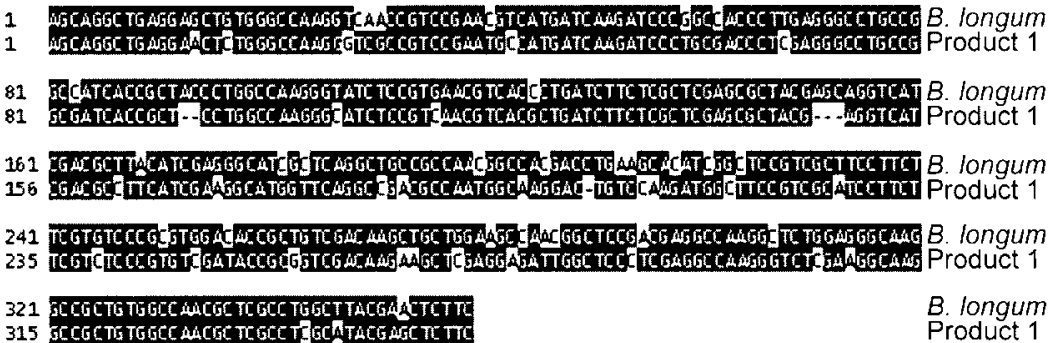

B

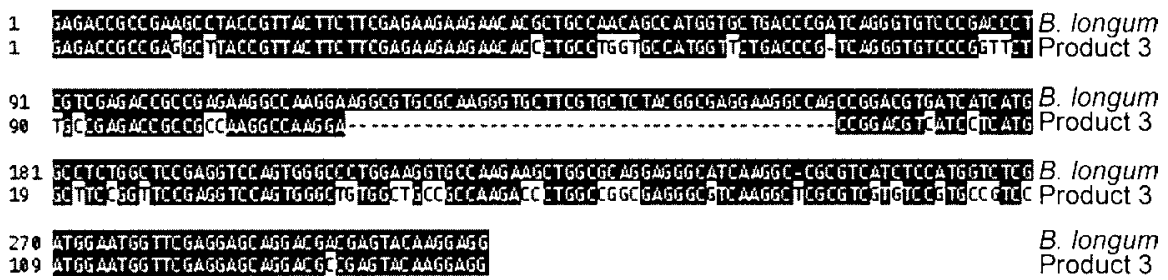

Fig 2. Nucleotide homologies are depicted between Bifidobacterium longum (accession No. AE014694.1) and sequences obtained from DNA sequencing of amplification Product 1 (A) and Product 3 (B) utilizing primers specific for Bifidobacterium bifidum. The shaded areas indicate residues that match each other exactly. The sequence homology between Product 1 and B. longum was 306 of 360 nucleotides, or $85 \%$, while the sequence homology between Product 3 and B. longum was 101 of $117(86 \%)$ and 121 of 148 $(81 \%)$, with a single $47-$ nucleotide gap. These results suggest that the amplified product is representative of a member of the Bifidobacterium genus which has not yet been deposited in the NCBI: genetic database.

\section{DISCUSSION}

The analysis of five probiotic products available to consumers revealed that overall cultures of commercially available probiotic products closely resemble the label claims. Two of the five products claim to contain Bifidobacterium bifidum, but this strain was not identified in these samples even after repeating the PCR with different primers, concentrations of magnesium chloride, and annealing temperatures. This finding may be attributable to the preparation standards of these manufacturers. In addition, an additional Lactobacillus species not listed on the label was identified in two products. It is possible that manufacturers utilize shared equipment to produce probiotics and therefore cross-contamination may occur, particularly in light of the high sensitivity inherent to PCR. It is possible that extending the scope of our methodology would have permitted identification of other bacterial species.

Colony counts were not evaluated during this preliminary study. However, the authors plan to expand this study to include a broader range of products, extended evaluation for contaminants, determination of actual colony counts, and use of real-time PCR procedures to determine the quantity of bacterial species present to compare with the manufacturer's label claims.

\section{REFERENCES}

1. Gionchetti P, Rizzello F, Venturi A, Campieri M: Probiotics in infective diarrhea and inflammatory bowel diseases. J Gastroenterol Hepatol 15:489-493, 2000

2. Vanderhoof JA: Probiotics: future directions. Am J Clin Nutr 73(Suppl):1152S-55S, 2001

3. Hooper LV, Gordon JI: Viewpoint: Commensal host-bacteria relationships in the gut. Science 292:1115-1118, 2001

4. Drisko JA, Giles C, Bischoff B: Probiotics in health maintenance and disease prevention. Alt Med Review 8(2):143-155, 2003

5. Hamilton-Miller JMT, Shah S: Letter to the Editors: Deficiencies in microbiological quality and labeling of probiotic supplements. Int J Food Microbiol 72:175-176, 2002

6. Song Y, Kato N, Liu C, Matsumiya Y, Kato H, Watanabe K: Rapid identification of 11 human intestinal Lactobacillus species by multiplex PCR assays using group-and species-specific primers derived from the 16S-23S rRNA intergenic spacer region and its flanking 23S rRNA. FEMS Microbiol Lett 187(2):167-173, 2000

7. Lick S, Drescher K, Heller KJ: Survival of Lactobacillus delbrueckii subsp. bulgaricus and Streptococcus thermophilus in the terminal lleum of fistulated Gottington minipigs. Appl Environ Microbiol Sept 67(9):4137-4143, 2001 